\title{
Use of a Weight of Evidence Approach to Determine the Likelihood of Adverse Effects on Human Health from the Presence of Uranium Facilities in Port Hope, Ontario
}

\author{
Rachel Lane ${ }^{1}$, Patsy Thompson ${ }^{1 *}$, Michael Ilin ${ }^{1}$, Marcelle Phaneuf ${ }^{2}$, Julie Burtt ${ }^{1}$, Pascale Reinhardt ${ }^{1}$ \\ ${ }^{1}$ Directorate of Environmental and Radiation Protection and Assessment, Canadian Nuclear Safety Commission, Ottawa, Canada; \\ ${ }^{2}$ International Atomic Energy Agency, Vienna, Austria. \\ Email: ${ }^{*}$ patsy.thompson@cnsc-ccsn.gc.ca
}

Received August $30^{\text {th }}, 2011$; revised October $1^{\text {st }}, 2011$; accepted November $3^{\text {rd }}, 2011$.

\begin{abstract}
The radium and uranium processing industry exists in Port Hope, Ontario, since 1932. Between 1932 and 1966, most of the waste material from these industries was deposited throughout the town. During these years, waste management practices did not prevent the spread of contamination. Several environmental and health studies have been conducted to assess the potential contamination effects in the Port Hope Community over the last 70 years. The current study used a weight of evidence approach to assess the types and levels of contaminants of concern in the environment, and the potential human exposure to these contaminants. Their toxicological and radio-toxicological properties were also assessed to determine their potential health effects. The results of these assessments were further compared to findings of earlier epidemiological studies of Port Hope residents and nuclear industry workers. The conclusions of this study indicated that: 1) Levels of exposure to radioactive and non-radioactive contaminants in Port Hope are below levels known to cause adverse health effects. 2) Epidemiological studies provide no evidence of health effects as a result of past and present activities of the Port Hope nuclear industries. 3) The environmental risk assessments and the epidemiological studies are consistent and support each other. 4) Port Hope's findings are consistent with the results of over 40 epidemiological studies conducted elsewhere on populations living around similar facilities or exposed to similar environmental contaminants.
\end{abstract}

Keywords: Uranium, Radiation, Cancer, Environment

\section{Introduction}

Radium and uranium processing industries have been operated in Port Hope, Ontario, since 1932. Low level radioactive wastes that contained large amounts of uranium, the radioactive decay products of uranium, and other minerals in the ore feed, such as arsenic, cobalt, copper, and nickel and trace amounts of antimony and lead, were produced during early years of operation when the waste management practices did not fully limit the spread of contamination. During these years, the levels of plant emissions were elevated and wastes were placed in a landfill or in various locations within the community. Scrap material used for construction of homes and buildings was also found to be contaminated.

From 1976 to 1981 , the most serious contamination in
Port Hope homes and businesses was remediated. As a result, over 100,000 tons of waste were removed and sent to a licensed waste management facility, while 600,000 tons were left in Port Hope in 11 large storage sites. A federally funded clean up project was further put in place to deal with the remaining volume of waste. Since 1984 uranium processing methods have improved and are now using uranium trioxide $\left(\mathrm{UO}_{3}\right)$ as feed material. In addition, better waste management practices have been put in place to reduce the waste and plant emissions that, nowadays, contain only uranium, ammonia and fluoride.

Despite better environmental performance of the current uranium processing operations, some health and environmental advocacy groups in the Port Hope community remain concerned about the health impacts that may have been caused by the presence of low-level ra- 
dioactive waste in Port Hope residential and public areas. During the last thirty years, various epidemiological studies of residents and workers have been undertaken to determine if some of the health effects observed in Port Hope residents could be related to the presence of these contaminants. Environmental risk assessments included measurements of the radiological and non-radiological contaminants in soil, air, water, and vegetables. They also estimated the multi-pathway of exposure and the health risks to the population using environmental monitoring data or dose re-construction methods based on a variety of guidelines or standards.

The current study is a comprehensive assessment of all existing data. This assessment used the weight of evidence approach to achieve its goal. This approach is recognized in the Canadian Environmental Protection Act (CEPA) [1], and by the U.S. Environmental Protection Agency [2] as a method whereby judgment involves consideration of the quality and adequacy of the available data and its consistency across the lines of evidence. The strength of the weight of evidence approach is that it requires a full interdisciplinary analysis of all the relevant information to develop an overall assessment and that it does not rely on any single study, whether positive or negative [3].

The weight of evidence assessment method includes reviewing site-specific doses, epidemiological studies and chemical specific toxicity data to evaluate exposure and potential health effects in a community [4].

This paper presents the results of the assessment conducted to determine the potential existence of health effects due to uranium and radium facilities operation in Port Hope.

\section{Material and Methods}

The qualitative weight of evidence standards, such as, the number of studies, the strength of association, the breadth and consistency of evidence, the correlation power and the biological plausibility, were used in this assessment. Data on the levels of contaminants in air, water, soil and garden produce were used in combination with health standards and guidelines to assess risks to the local population. The risk estimates were then compared to the results of epidemiological studies conducted on Port Hope residents and nuclear industry workers. The criteria used to weigh the various lines of evidence were the same as the US EPA criteria [2] and were as follow:

- shortness of the period of time between exposure and outcome (taking into consideration latency period);

- consistency between results from independent studies;

- strength of association between the substance and the effect;

- reliability of exposure data;

- absence of biases or confounding factors; and

- strength of the statistical significance for a given effect.

Exposure estimates were derived from more than 30 environmental epidemiological studies that covered the period from the early 1930's to present. Thirteen epidemiological studies considered all health outcomes and all causes of mortality. To aid in the interpretation of these studies, plausible health effects in Port Hope residents were identified through a review of the available radiological and toxicological peer reviewed literature for the following contaminants of concern: radon, radium-226, uranium, arsenic, ammonia, and fluorides.

In order to test consistency, the weight of evidence approach was used to compare the findings of the Port Hope epidemiological studies with the environmental risk and with more than 40 additional similar epidemiological studies conducted elsewhere in the world.

In accordance with US EPA's guidance [5] on scientific information intended to support regulatory decisions, the assessment was also peer-reviewed by internal experts and external independent experts [6].

\section{Results}

\subsection{Port Hope Residents’ Exposure to Environmental Contaminants}

The levels of exposure to radioactive and non-radioactive contaminants of potential concern were estimated based on a large amount of environmental monitoring data collected since the mid-1970s [7-13], and from dose reconstruction [14].

Exposure estimates were obtained from multi-pathway calculations of intake using the International Commission on Radiation Protection (ICRP) "critical group" concept [15]. This entails conservative assumptions, such as occupancy factors, origin of food and water, and consumption of contaminated soil by infants.

\subsection{Radioactive Contaminant}

Table 1 provides dose estimates of radioactive contaminants to members of the public in Port Hope, for the periods before and after the remediation activities (conducted from 1976 to 1981) combined, and for the current period of operation of the uranium processing industry.

The average dose resulting from natural background in Canada is about $2.4 \mathrm{mSv} / \mathrm{year}$; this is in the same range as elsewhere in the world. Port Hope's industrial sources of radiation represent an incremental exposure that is within the geographical variability of natural background. At this low level of exposure no adverse health effects 
Table 1. Radiation Levels in Port Hope.

\begin{tabular}{cc}
\hline Annual radiation doses & mSv/year \\
\hline Radon (indoor) in Port Hope (1955-1993) & $0.69-1.46$ \\
Gamma (indoor) in Port Hope (1955-1993) & $0.25-0.27$ \\
Cameco Port Hope Conversion Facility (2007) & 0.064 \\
Cameco Fuel Production Facility (2007) & 0.004 \\
\hline
\end{tabular}

are expected. Studies have indicated that incidence of cancer in populations chronically exposed to radiation doses lower than $100 \mathrm{mSv}$ is not statistically different from incidence of cancer due to background exposure in the general population [16].

\subsection{Non-Radioactive Contaminants}

The levels of contaminants (uranium, arsenic, fluoride, ammonia and other non-radiological contaminants) measured in Port Hope's air, water, and vegetation, have been compared to the current health protection limits or guidelines (Table 2).

Concentrations of uranium and arsenic in some of Port Hope soil samples are above soil quality guidelines due to historic contamination. Nonetheless, recent studies have indicated that the implementation of emission abatement technology at the Port Hope refinery in 1984 has resulted in lower uranium concentrations in soils ${ }^{4}$. Stack testing has also shown that arsenic is no longer being discharged from this facility. Exposure assessments have shown low intakes of uranium and arsenic mainly due to their low bioavailability in soils ${ }^{5}$ and their relatively

Table 2. Comparison of the current levels of some contaminants present in Port Hope to guidelines/standards.

\begin{tabular}{|c|c|c|c|c|c|c|}
\hline \multicolumn{4}{|c|}{ Guidelines/Standards } & \multicolumn{3}{|c|}{ Current Levels in Port Hope } \\
\hline & $\operatorname{Air}^{1}$ & Water $^{2}$ & Soil $^{3}$ & Air & Water & Soil \\
\hline Uranium & $\begin{array}{c}0.03 \\
\mu \mathrm{g} / \mathrm{m}^{3}\end{array}$ & $\begin{array}{c}0.02 \\
\mathrm{mg} / \mathrm{L}\end{array}$ & $\begin{array}{c}23 \\
\mathrm{mg} / \mathrm{kg}\end{array}$ & $\begin{array}{c}0.00028- \\
0.005 \\
\mu \mathrm{g} / \mathrm{m}^{3}\end{array}$ & $\begin{array}{c}0.00055 \\
\mathrm{mg} / \mathrm{L}\end{array}$ & $\begin{array}{c}0.24-93.6 \\
\mathrm{mg} / \mathrm{kg}\end{array}$ \\
\hline Arsenic & N/A & $\begin{array}{l}0.025 \\
\mathrm{mg} / \mathrm{L}\end{array}$ & $\begin{array}{c}12 \\
\mathrm{mg} / \mathrm{kg}\end{array}$ & N/A & $\begin{array}{c}0.0005- \\
0.002 \mathrm{mg} / \mathrm{L}\end{array}$ & $\begin{array}{c}1-94 \\
\mathrm{mg} / \mathrm{kg}\end{array}$ \\
\hline Fluoride & N/A & $\begin{array}{c}1.5 \\
\mathrm{mg} / \mathrm{L}\end{array}$ & N/A & N/A & $\leq 0.25 \mathrm{mg} / \mathrm{L}$ & N/A \\
\hline Ammonia & $\begin{array}{c}100 \\
\mu \mathrm{g} / \mathrm{m}^{3}\end{array}$ & $1 \mathrm{mg} / \mathrm{L}$ & N/A & $\begin{array}{c}1.5-15.2 \\
\mu \mathrm{g} / \mathrm{m}^{3}\end{array}$ & $\begin{array}{c}0.12-0.21 \\
\mathrm{mg} / \mathrm{L}\end{array}$ & N/A \\
\hline
\end{tabular}

${ }^{1}$ Ontario Ambient Air Quality Criteria.

${ }^{2}$ Ontario Drinking Water Standards.

${ }^{3}$ Canadian Council of Ministers of the Environment Soil Quality Guideline for the Protection of Environmental Health (residential/parkland use).

${ }^{4}$ EcoMatters, 2004. Uranium Concentrations in Port Hope Soils and Vegetation and Toxicological Effect on Soil Organisms. Final Report to the Canadian Nuclear Safety Commission.

${ }^{5}$ SENES Consultants Limited, 2008. Soil Characterization and Evaluation Study at Port Hope. Final Report. Prepared for Cameco Corporation. short biological half-life. Exposure to arsenic in Port Hope is estimated to result in a skin cancer risk similar to the average estimated cancer risk for arsenic for the average Ontario residents ${ }^{6}$.

The contaminants that have mostly accumulated over time in Port Hope soils are uranium, antimony, chromium, copper, nickel, cadmium, cobalt, selenium and zinc. Levels of exposure are low and risk quotients remain below 1. Consequently, no adverse health effects to Port Hope residents are expected to be linked to these environmental contaminants [8].

\subsection{Identification of the Plausible Health Effects from the Contaminants Present in Port Hope}

The contaminants of potential concern in Port Hope occur both naturally and as a result of the activities of the radium and uranium refining and processing industry in the community. The effects of ionizing radiation, uranium, arsenic, fluoride and ammonia are well understood. They have been extensively studied in laboratory animals and cell cultures and through epidemiological studies conducted in human populations.

Many comprehensive toxicological data reviews have been conducted nationally and internationally to establish standards and guidelines to protect human health from exposures in occupational settings [17-20] and from environmental exposures. These criteria are, for example, drinking water standards and air and soil quality standards $[5,21,22]$ and [23]. Plausible health effects of contaminants of concern in Port Hope were identified and weighted for their strength of evidence taking into account their toxicological and radio-toxicological evaluation and exposures estimation (Table 3). The result of this assessment was further compared with the findings of epidemiological studies.

\subsection{Epidemiological Studies Conducted in Port Hope}

Thirteen epidemiological studies were conducted in Port Hope in the past 30 years. They included the period of remediation of the low level radioactive waste (1976 to 1981), the period of the solvent extraction plant (1967 to 1984) when uranium emissions were elevated and current times (from 1984 to the present) when the implementation of mitigation measures significantly reduced uranium emissions. The studies assessed all causes of death, all cancers and all birth defects.

Among these thirteen studies:

${ }^{6}$ CANTOX, 1999. Deloro Village Exposure Assessment and Health Risk Characterization for Arsenic and Other Metals. Final Report. Cantox Environmental Inc. 
Table 3. Plausible Health Effects Associated with Exposure to Contaminants due to the Presence of the Radium and Uranium Processing Industry in Port Hope.

\begin{tabular}{|c|c|c|c|}
\hline Contaminants & Most plausible health effects & Probability of occurrence & $\begin{array}{c}\text { Strength of the } \\
\text { supporting } \\
\text { evidence }\end{array}$ \\
\hline $\begin{array}{l}\text { Uranium } \\
\left(\mathrm{UO}_{3}, \mathrm{UF}_{6}\right)\end{array}$ & $\begin{array}{l}\text { Kidney disease } \\
\text { Uranium at very high levels can cause kidney } \\
\text { disease in animal experiments. In humans, very } \\
\text { high levels of uranium can cause changes to } \\
\text { kidney cells, which are largely reversible }\end{array}$ & $\begin{array}{l}\text { Unlikely } \\
\text { Evidence: Risk quotients are generally below } 1 . \\
\text { Levels of uranium in soil in some locations are } \\
\text { above the soil quality guidelines for protection } \\
\text { of human life but bioavailability is low }\end{array}$ & $\begin{array}{l}\text { Moderate to } \\
\text { high }\end{array}$ \\
\hline $\begin{array}{l}\text { Radon } \\
\text { Radon decay products } \\
\mathrm{UO}_{2}\end{array}$ & $\begin{array}{l}\text { Lung Cancer } \\
\text { Radon and its decay products, and long-lived } \\
\text { radioactive dust }\left(\mathrm{UO}_{2}\right) \text { are known to cause lung } \\
\text { cancer. }\end{array}$ & $\begin{array}{l}\text { Low probability of occurrence } \\
\text { Residential radon exposure ranged from } 0.69 \\
-1.46 \mathrm{mSv} / \text { year. Doses are either below the } \\
\text { regulatory limit of } 1 \mathrm{mSv} / \text { year or within the } \\
\text { range of natural background in the area }\end{array}$ & Moderate \\
\hline $\begin{array}{l}\text { Radium } \\
\text { (Ra-226) }\end{array}$ & $\begin{array}{l}\text { Bone Cancer } \\
\text { Radium, if ingested, can deposit in the bone } \\
\text { and cause bone cancer at very high levels, with } \\
\text { a threshold of about } 10 \mathrm{~Sv} \text {. }\end{array}$ & $\begin{array}{l}\text { Unlikely } \\
\text { Total radiation doses from uranium, Ra- } 226 \\
\text { and other uranium decay products are estimated } \\
\text { to have been below } 1 \mathrm{mSv} / \text { year even during the } \\
\text { early period }\end{array}$ & High \\
\hline Arsenic & $\begin{array}{l}\text { Skin cancer, tumors of the bladder and the } \\
\text { lung, potential for liver, kidney and prostate } \\
\text { tumours (high exposures) }\end{array}$ & $\begin{array}{l}\text { Low probability of occurrence } \\
\text { Arsenic exposure from historical releases in } \\
\text { Port Hope represents an incremental life time } \\
\text { risk of } 1 \text { excess skin cancer risk every } 139 \\
\text { years }\end{array}$ & $\begin{array}{l}\text { Moderate to } \\
\text { high }\end{array}$ \\
\hline Ammonia & $\begin{array}{l}\text { Lung edema (high acute exposures) } \\
\text { Eye, nose and throat irritation } \\
\text { (lower exposures) }\end{array}$ & $\begin{array}{l}\text { Unlikely } \\
\text { Ammonia air concentrations are well below the } \\
\text { air quality standard }\end{array}$ & High \\
\hline Fluoride & $\begin{array}{l}\text { Yellowing of the teeth, hypothyroidism, } \\
\text { brittle bones and teeth } \\
\text { (chronic low level oral exposure) }\end{array}$ & $\begin{array}{l}\text { Unlikely } \\
\text { Fluoride concentrations are well below } \\
\text { drinking water standard }\end{array}$ & High \\
\hline $\begin{array}{l}\text { Lead-214, } \\
\text { Bismuth-214 } \\
\text { (gamma-ray radiation } \\
\text { emitting uranium } \\
\text { decay products) }\end{array}$ & $\begin{array}{l}\text { Leukemia, breast cancer, lung cancer and other } \\
\text { cancers (associated with high whole body } \\
\text { gamma ray doses) }\end{array}$ & $\begin{array}{l}\text { Low probability of occurrence } \\
\text { Indoor gamma radiation doses in Port Hope } \\
\text { (1955-1993) range from } 0.25 \text { to } 0.27 \mathrm{mSv} \text { per } \\
\text { year and are below the regulatory limit of } 1 \\
\mathrm{mSv} / \text { year. }\end{array}$ & $\begin{array}{l}\text { Moderate to } \\
\text { high }\end{array}$ \\
\hline
\end{tabular}

- nine were descriptive ecological studies that compared the rates of all causes of death, of cancer incidence, and of birth defects among Port Hope residents with the general population of Ontario, similar communities, and the rest of the population of Canada [24-35];

- two were case-control studies, one investigated the relationship between lung cancer and residential radon exposure in homes [36,37], the second one studied if there was an association between childhood leukaemia and father's occupational exposure to ionizing radiation before the child's conception [38]; and two were cohort studies on Eldorado workers [39,40] and provided data on approximately 50 years of mortality and 30 years of cancer incidence for Port Hope's radium and uranium refining and processing facility workers.

The epidemiological studies provided no evidence of excess kidney disease or bone cancer. During the entire period of the radium and uranium refining and processing industry operation in Port Hope, there has been no statistically significant excess of kidney disease mortality in residents or in radium and uranium workers. Similarly no statistically significant excess of bone cancer incidence or mortality in residents or in radium or uranium workers (Figures 1(a), 1(b), 2(a) and 2(b)) was found. No relationship could be established between workers' occupational radiation exposures and kidney disease mortality or bone cancer incidence or mortality [6].

A small evidence of excess in lung cancer was found in Port Hope women in the period from 1986 to1996, but no excess could be demonstrated in the period from 1971 to 1985 in women, or in men between 1971 and 1996. The same observation was made in Northumberland County and in the HKPR District indicating that elevated rates of lung cancer in women (1986-1996) was not specific to Port Hope [38].

Similarly, no statistically significant excess lung can- 

from the Presence of Uranium Facilities in Port Hope, Ontario

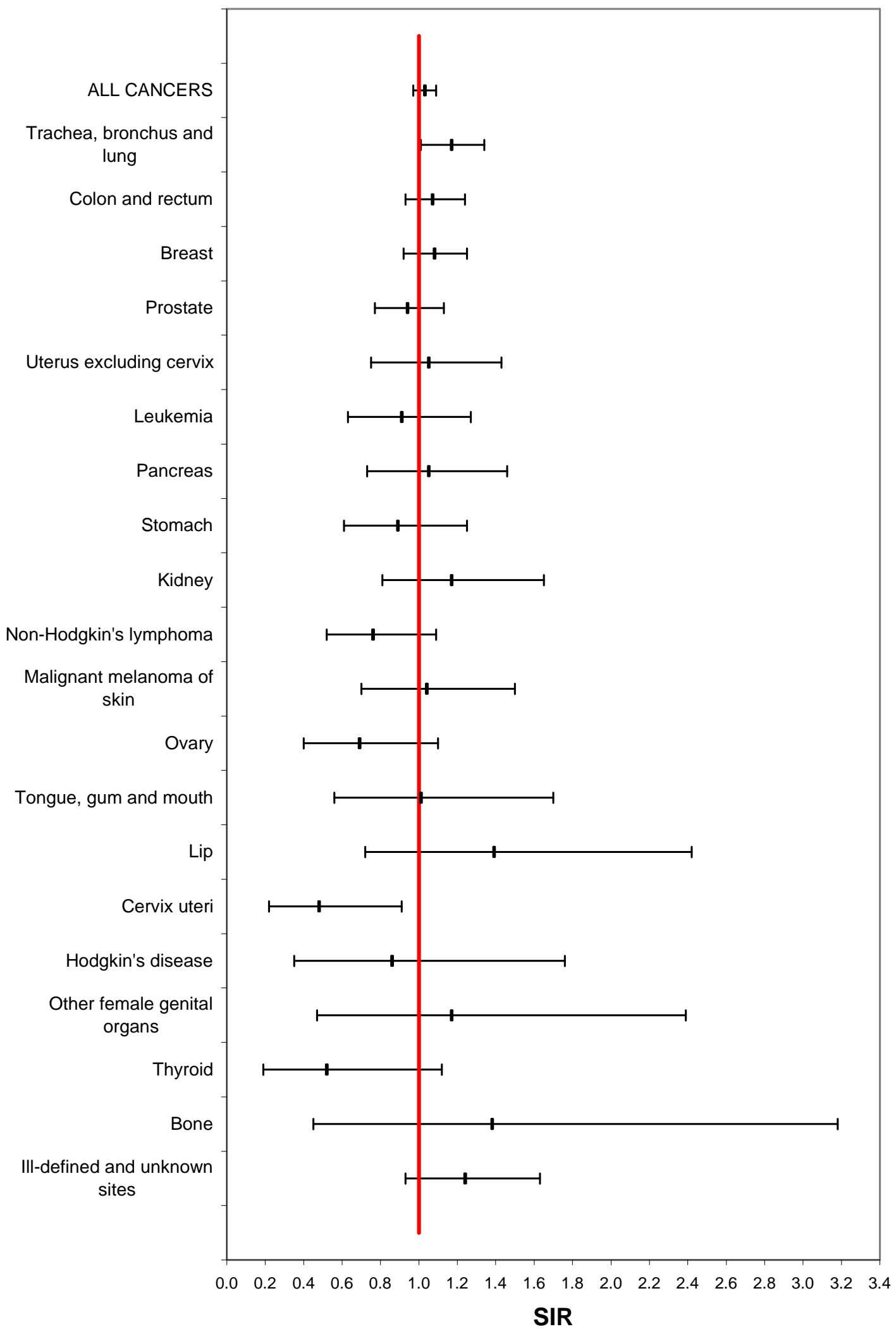

(a) 


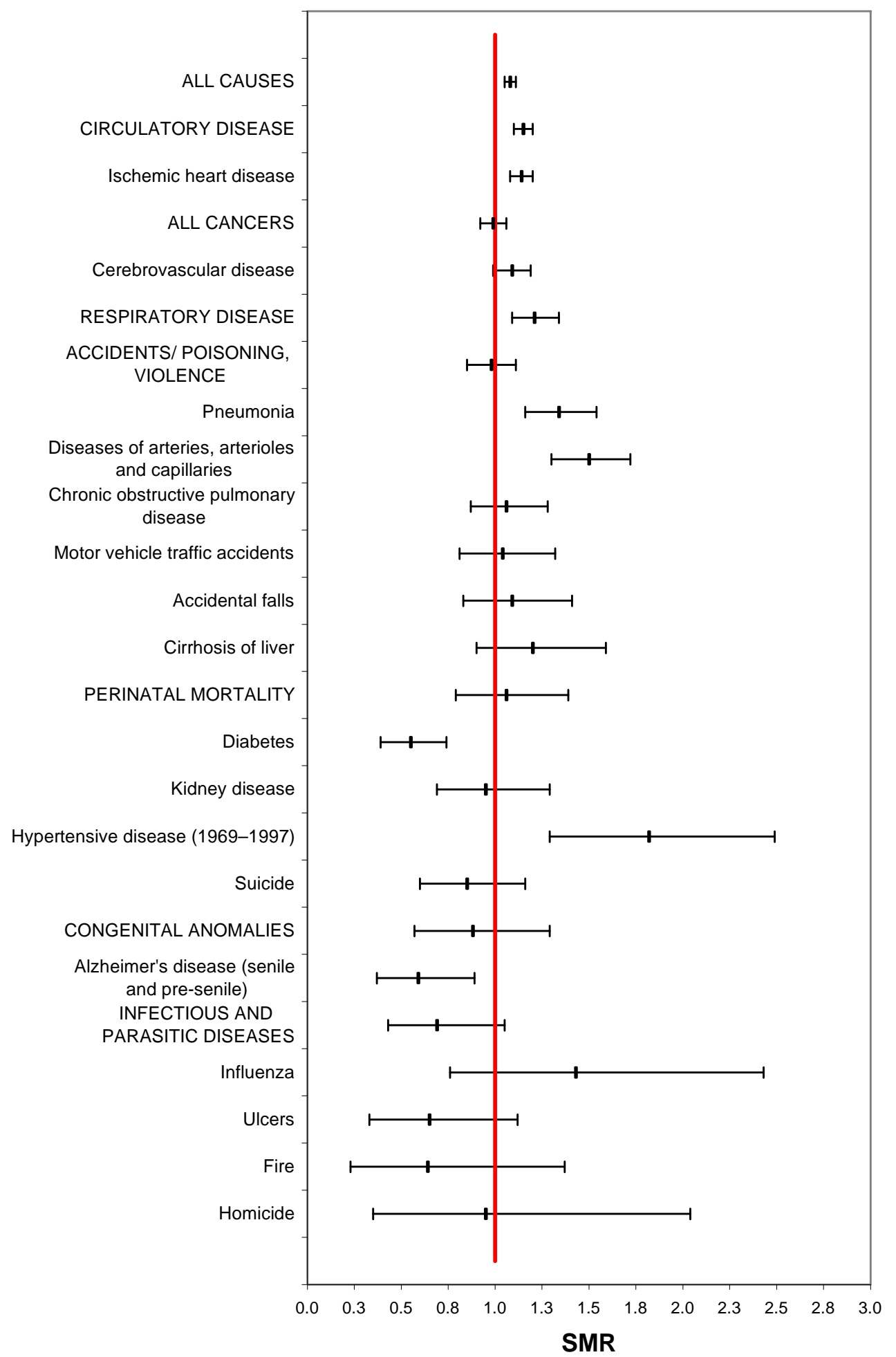

(b)

Figure 1. (a) Standardized Incidence Ratios (95\% Confidence Intervals) For Selected Cancers for Port Hope, Ontario Compared With Ontario Cancer Incidence Rates, from 1971 to 1996, Both Sexes Combined, All Ages (0-85+ years); (b) Standardized Mortality Ratios (95\% Confidence Intervals) For Selected Causes of Death for Port Hope, Ontario Compared with Ontario Mortality Rates, from 1956 to 1997, Both Sexes Combined, All Ages (0-85+ years). 

from the Presence of Uranium Facilities in Port Hope, Ontario

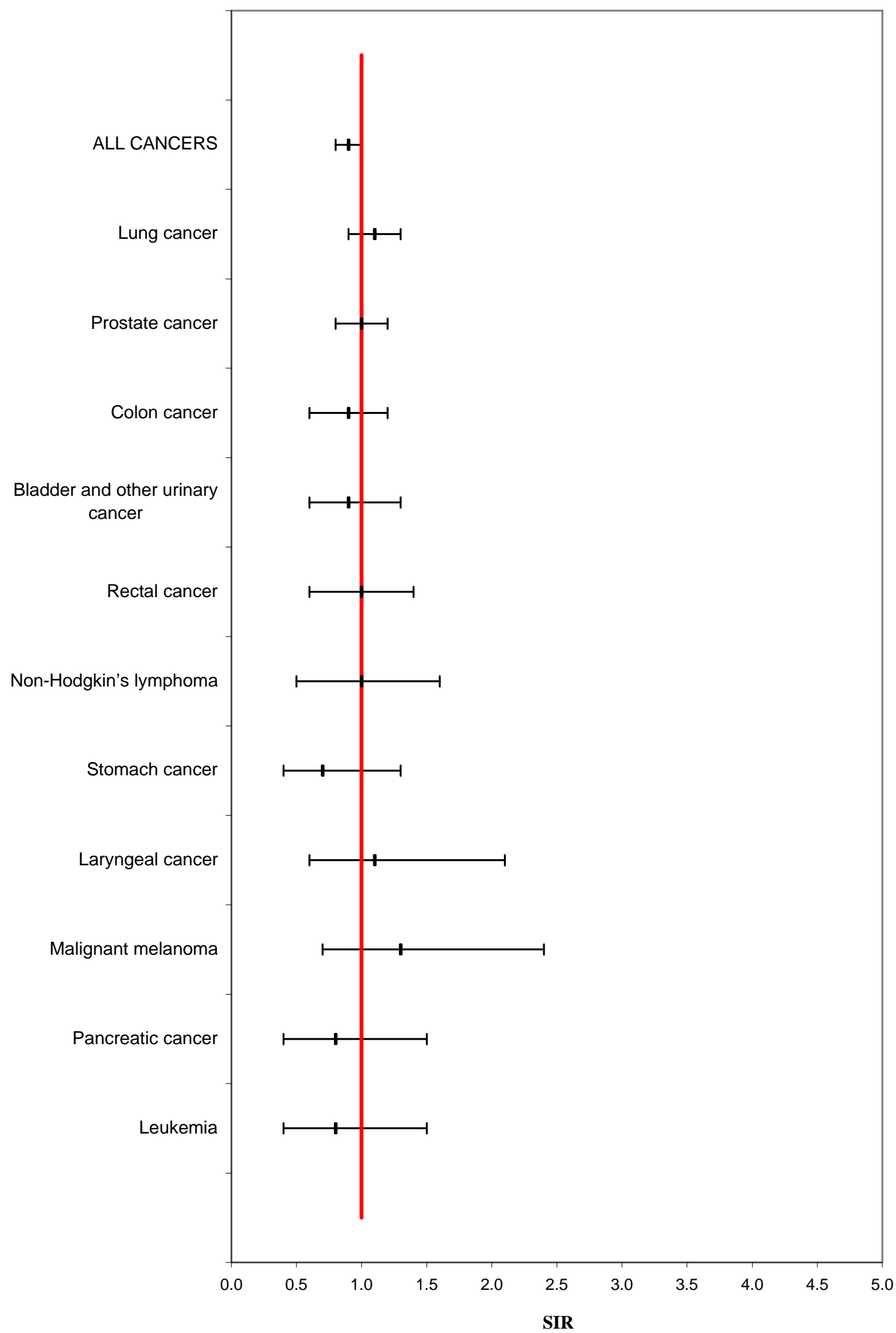

(a) 


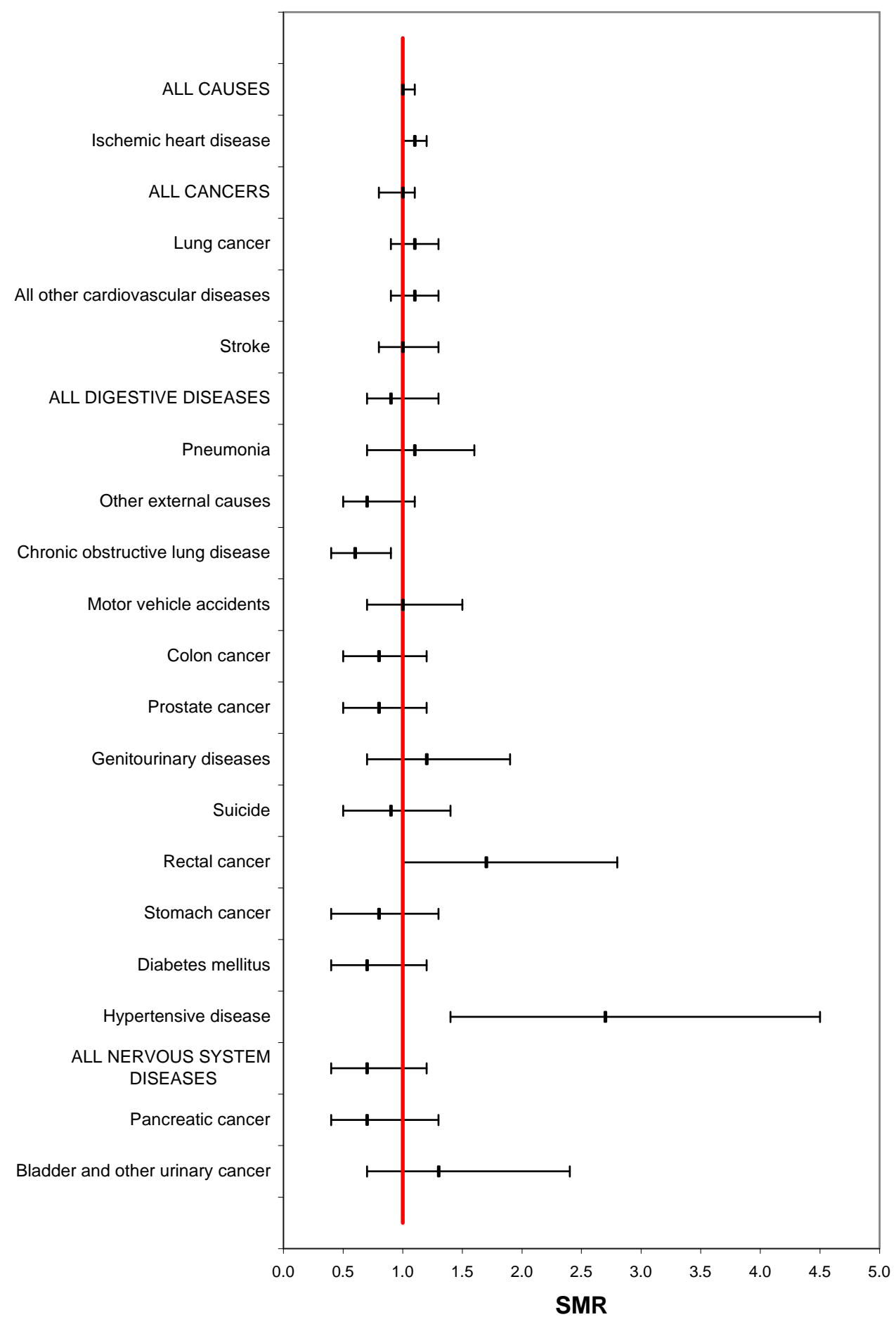

(b)

Figure 2. (a) Standardized Incidence Ratios (95\% Confidence Intervals- adjusted for age (five year intervals) and calendar year at risk (five year intervals)) For Selected Cancers for Port Hope Eldorado Male Employees Compared With Canadian Male Cancer Incidence Rates, from 1969 to 1999; (b). Standardized Mortality Ratios (95\% Confidence Intervals - adjusted for age (five year intervals) and calendar year at risk (five year intervals)) For Selected Cancer Deaths for Port Hope Eldorado Male Employees Compared With Canadian Male Mortality Rates from 1950 to 1999. 
cer incidence or mortality could be observed in Port Hope nuclear workers, and more importantly, there was no statistically significant relationship between workers' occupational radiation exposures and lung cancer (Table 4).

Workers' average cumulative exposures were $52 \mathrm{mSv}$ for radon and $101.5 \mathrm{mSv}$ for gamma radiation [39] and [40]. Many of these workers were living in the community which implied they were also exposed to some radiation at home. The case-control study conducted in Port Hope [37] on residential radon exposure and lung cancer showed no conclusive evidence of an increased risk of lung cancer in "problem homes" (where annual exposure was above 0.229 Working Level Months or $1.15 \mathrm{mSv}$ per year). In addition, no statistically significant excess of lung cancer mortality in Port Hope residents for the period from1954 to 1997 [24,25,33] and [6] was demonstrated.

Table 5 summarizes the weight of evidence obtained from the various epidemiological studies conducted in Port Hope taking into consideration the robustness of each study; cohort studies being weighted more strongly than case-control and ecological studies.

\section{Discussions}

Taken together, the findings of the 13 epidemiological studies conducted on the general population and the radium and uranium workers support and strengthen the evidence obtained from the risk assessments that adverse health effects are unlikely to be the result of exposure of Port hope residents to environmental contaminants from the radium and uranium processing.

\subsection{Circulatory Diseases}

In the 1956-1997 period, the overall excess of mortality in Port Hope was dominated by an excess of circulatory disease, which represented over $50 \%$ of all deaths [33]. Circulatory disease is recognized to be the leading cause of death in Canada [41]. The scientific data available to date are not sufficient to conclude that there is a causal relationship between ionizing radiation exposure and cardiovascular disease for doses lower than 1 to $2 \mathrm{~Sv}$ [42]. Given the level of radiation in Port Hope, $0.69-1.46$ $\mathrm{mSv} /$ year from 1967 to 1976 and $0.004-0.064 \mathrm{mSv} /$ year in 2007 , it is highly unlikely that circulatory diseases could be associated with radiation in the municipality. The excess observed in circulatory diseases is likely mostly due to other risk factors, such as smoking, obesity, physical inactivity, high blood pressure, diabetes, stress and alcohol consumption [43].

The same excess in circulatory disease was found in the whole Northumberland County which confirmed it was not specific to Port Hope. The Rapid Risk Factor Surveillance System (RRFSS) also reported that the overall community (HKPR District) had a high prevalence of risk factors for circulatory disease, including poor diet, physical inactivity and high rates of cigarette smoking [35]. Meanwhile, Eldorado radium and uranium workers' overall mortality for all causes of death was generally comparable with the mortality of the general male population of Canada.

\subsection{All Cancers except Lung Cancer}

Even if increases in some cancers (e.g. colorectal, brain and other nervous system, esophagus, lip, pharynx, nose/ sinuses) could be observed after stratification of the results by age group, sex, time period, and residence coding, it was unlikely that these cancers could be related to activities of the nuclear industry in Port Hope. The lack of biological plausibility and of experimental evidence made it impossible to link them to the presence of contaminants of concern in Port Hope.

The available evidence indicates that colorectal cancer is inducible by high whole-body gamma ray doses, but the risk appears very low at doses lower than 1 Gy [15] [42] and [44]. Ionizing radiation can induce brain and central nervous system tumors, but most of these radiation-associated tumors are benign [42]. Cancers of the esophagus, lip, pharynx, nose/sinuses, and lung are most likely linked to tobacco smoking [35,45] and [46]. Other than lung cancer, these cancers are not known to be associated with exposures to environmental contaminants such as those present in Port Hope. Hence, it was not surprising that no relationship was found between these cancers and occupational radiation exposures in the Eldorado workers [39] and [40].

\subsection{Lung Cancer}

The excess in lung cancer incidence in women observed in one time period (1986 to 1996) in Port Hope is unlikely to be related to environmental contaminants exposure since this was not observed during the earlier period [24] and [25] when the level of contaminants was higher; the latency period having been sufficient to have given the disease the opportunity to appear during the earlier period. A temporal relationship is therefore absent.

In addition, a case control study conducted in Port Hope [36] and [37] has not been able to establish a conclusive relationship between residential radon and lung cancer. The levels of residential radon in Port Hope remained much lower than those to which radium and uranium industry workers were exposed [39] and [40] and the workers did not show any excess in lung cancer incidence or mortality. The lack of relationship between lung 
Table 4. Excess Relative Risk Estimates for Lung Cancer Mortality and Incidence due to Radon Decay Products/100 Work Level Months exposure in Port Hope Eldorado Male Employees, 1950-1999 [40].

\begin{tabular}{ccccc}
\hline Lung Cancer & Observed & ERR Estimate & 95\% Confidence Interval & p-value \\
\hline Mortality (1950-1999) & 101 & 0.18 & $-0.10,1.49$ & 0.59 \\
Incidence (1969-1999) & 110 & 0.68 & $-0.23,3.07$ & 0.17 \\
\hline
\end{tabular}

Table 5. Strength of evidence of the potential adverse impacts on human health based on the epidemiological studies conducted in Port Hope's residents and in uranium and radium workers.

\begin{tabular}{|c|c|c|c|}
\hline Disease & Evidence Description & Strength of evidence & References \\
\hline Kidney disease & $\begin{array}{l}\text { No evidence of excess kidney disease - No statistically } \\
\text { significant excess kidney disease mortality in Port Hope } \\
\text { residents or in radium and uranium workers for the entire } \\
\text { period of study. }\end{array}$ & High & $\begin{array}{c}{[24][25][31][33][39] \text { and }} \\
{[40]}\end{array}$ \\
\hline \multirow{5}{*}{ Lung cancer } & Little evidence of excess lung cancer & & \\
\hline & $\begin{array}{l}\text { No statistically significant excess lung cancer incidence or } \\
\text { mortality in Port Hope radium and uranium workers. }\end{array}$ & High & {$[40]$ and $[41]$} \\
\hline & $\begin{array}{l}\text { No conclusive evidence of increased lung cancer risk from } \\
\text { residential radon exposure in "problem homes" in the } \\
\text { case-control study. }\end{array}$ & Moderate & [37] \\
\hline & $\begin{array}{l}\text { No statistically significant excess lung cancer mortality in Port } \\
\text { Hope residents from } 1956 \text { to } 1997 \text {. }\end{array}$ & Moderate & [32] [33] and [37] \\
\hline & $\begin{array}{l}\text { Statistically significant excess lung cancer incidence in women } \\
\text { in Port Hope from } 1986 \text { to } 1996 \text {. No excess was noted during } \\
\text { other time periods or in men. }\end{array}$ & Moderate & [32] \\
\hline \multirow[b]{2}{*}{ Bone cancer } & No evidence of excess bone cancer & \multirow{3}{*}{ High } & \multirow{3}{*}{ [32] [33] [39] and [40] } \\
\hline & $\begin{array}{l}\text { No statistically significant excess bone cancer incidence or } \\
\text { mortality in Port Hope residents or radium and uranium } \\
\text { workers for the entire period of study. }\end{array}$ & & \\
\hline \multirow[b]{2}{*}{$\begin{array}{l}\text { Skin cancer and } \\
\text { other diseases }\end{array}$} & No evidence of health effects from occupational exposures & & \\
\hline & $\begin{array}{l}\text { No statistically significant relationship between workers' } \\
\text { occupational exposures and any cause of death or cancer } \\
\text { incidence. }\end{array}$ & High & [40] \\
\hline
\end{tabular}

cancer and occupational exposures in these workers provides another line of evidence that environmental radon levels in Port Hope are unlikely to cause lung cancer.

\section{Conclusions}

The findings of the environmental risk assessments and the epidemiological studies conducted in Port Hope are consistent with each other (Tables 3 and 5) and with other epidemiological studies conducted on similar populations elsewhere, [47-57]. Other studies on populations exposed to high concentrations of uranium and radionuclides in drinking water [58-60] also support this conclusion.

The weight of evidence approach was used in the current study to provide a structured framework in order to conduct a transparent interdisciplinary analysis of the numerous health and environmental studies conducted in Port Hope over the last 30 years. By considering all the available lines of evidence and their relative strengths it can be concluded that there is no evidence that adverse health effects have occurred or are likely to occur as a result of the operations of the nuclear industry in the municipality of Port Hope.

\section{REFERENCES}

[1] "Canadian Environmental Protection Act (CEPA)," Canada Gazette Part III, Vol. 22, No. 3, 4 November 1999. http://www.ec.gc.ca/lcpe-cepa/default.asp?lang=En\&n=2 4374285-1

[2] U.S. Environmental Protection Agency, "Proposed Guidelines for Carcinogen Risk Assessment," EPA, Washington EPA/600/P-92/003C, 1996.

[3] R. G. Hetes, "Science, Risk, and Risk Assessment and Their Role (s) Supporting Environmental Risk Management," Law, Science and the Environment Forum: A Meeting of Minds Lewis and Clark Law School, 19-20 April 2007.

[4] Agency for Toxic Substances and Disease Registry 
(ATSDR), "The Assessment Process: An Interactive Learning Program," 2005.

http://www.atsdr.cdc.gov/training/public-health-assessme nt-overview/html/ module2/sv18.html.

[5] U.S. EPA Science Policy Council, "Peer Review Handbook," 3rd Edition, EPA 100/B-06/002, 2006. http://www.epa.gov/peerreview/pdfs/peer review handb ook_2006.pdf.

[6] Canadian Nuclear Safety Commission (CNSC), "Understanding Health Studies and Risk Assessments Conducted in the Port Hope Community from the 1950s to the Present," 2009.

http://www.nuclearsafety.gc.ca/eng/pdfs/Info-0781-en.pd $\mathrm{f}$

[7] Ontario Ministry of the Environment (MOE), "Phytotoxicology Technical Memorandum. A Review of Phytotoxicology Investigations: 1974-2003 Cameco Corporation-Port Hope," Report No. Phyto-S3147-2003.

[8] Ontario Ministry of the Environment (MOE), Hazardous Contaminants Branch, "Assessment of Human Health Risk of Reported Soil Levels of Metals and Radionuclides in Port Hope," Queen's Printer for Ontario, 1991.

[9] B. L. Tracy and D. P. Meyerhof, "Health Evaluation of Uranium Emissions in Port Hope, An Assessment Submitted to the Atomic Energy Control Board," 1981.

[10] B. L. Tracy and D. P. Meyerhof, "Uranium Concentrations near a Canadian Uranium Refinery," Atmospheric Environment, Vol. 21, No. 1, 1987, pp. 165-172. doi:10.1016/0004-6981(87)90281-2

[11] B. L. Tracy, F. A. Prantl and J. M. Quinn, "Transfer of 226Ra, 210Pb, and Uranium from Soil to Garden Produce: Assessment of Risk," Health Physics, Vol. 44, No. 5, 1983, pp. 469-477. doi:10.1097/00004032-198305000-00001

[12] B. Ahier and B. L. Tracy, "Uranium Emissions in Port Hope, Ontario," Journal of Environmental Radioactivity, Vol. 34, No. 2, 1997, pp. 187-205. doi:10.1016/0265-931X(96)00008-2

[13] Health Canada, "Environmental radioactivity in Canada 1989-1996," Available from Environmental Radiation Hazards Division, Radiation Protection Bureau, Health Canada, 2001.

[14] SENES Consultants Limited, "Technical Report on Average and Cumulative Exposures for Residents of Port Hope, Ontario Resulting from Historic Low-Level Radioactive Wastes in the Town," Prepared for Environmental Radiation Hazards Division, Bureau of Radiation and Medical Devices, Health Protection Branch, Health Canada, 1995 .

[15] International Commission on Radiological Protection (ICRP), "Recommendations of the International Commission on Radiological Protection," ICRP Publication 60, Annals of the ICRP, Vol. 21, No. 1-3, 1990, pp. 1201.

[16] United States National Research Council (NRC), "Health Risks from Exposure to Low Levels of Ionizing Radia- tion: BEIR VII Phase 2. Board on Radiation Effects Research," The Committee on the Biological Effects of Ionizing Radiations (BEIR), The National Academies Press, Washington DC, 2006.

[17] Agency for Toxic Substances and Disease Registry (ATSDR), "Toxological Profile for Uranium," 1999. http://www.atsdr.cdc.gov/toxprofiles/tp150.pdf

[18] Agency for Toxic Substances and Disease Registry, "Toxicological Profile for Fluorides, Hydrogen Fluoride, and Fluorine," 2003.

http:/www.davidborowski.com/work/ATSDR\%20ToxPr ofiles\%202007/Data/FLUORIDES.pdf

[19] Agency for Toxic Substances and Disease Registry, "Toxicological Profile for Ammonia," 2004. http://www.atsdr.cdc.gov/ToxProfiles/tp126-p.pdf

[20] Agency for Toxic Substances and Disease Registry, "Toxicological Profile for Arsenic," 2007. http://www.atsdr.cdc.gov/ToxProfiles/tp2-p.pdf

[21] World Health Organization (WHO), "Depleted Uranium: Sources, Exposure and Health Effects," 2001. http://www.who.int/ionizing_radiation/pub_meet/en/Depl uraniumintro.pdf

[22] Health Canada, "Guidelines for Canadian Drinking Water Quality: Guideline Technical Document. Radiological Characteristics," 2007.

http://www.hc-sc.gc.ca/ewh-semt/pubs/water-eau/index-e ng.php\#tech_doc.

[23] Health Canada, "Government of Canada Radon Guideline," 2008.

http://hc-sc.gc.ca/ewh-semt/radiation/radon/guidelines_li gnes_directricie-eng.php.

[24] R. Kusiak and P. J. Howe, "Standardized Mortality Ratios in Selected Urban Areas in Ontario between 1954 and 1978," Ontario Ministry of Labour, Toronto, Ontario, 1984.

[25] Health and Welfare Canada and Statistics Canada, "Mortality Atlas of Canada, Volume 3: Urban Mortality," Ministry of Supply and Services, Ottawa, (Catalogue No. H49-6/3-1984 and Unpublished Appendix Tables), 1984.

[26] E. A. Clarke, J. McLaughlin, and T. W. Anderson, "Childhood Leukemia around Canadian Nuclear Facilities-Phase I. Final Report," AECB Report INFO-0300.1. Atomic Energy Control Board, Ottawa, Canada, 1989.

[27] E. A. Clarke, J. McLaughlin and T. W. Anderson. 1991, "Childhood Leukemia around Canadian Nuclear Facilities-Phase II. Final Report," AECB Report INFO0300.2., Atomic Energy Control Board, Ottawa, Canada, 1991.

[28] J. R. McLaughlin, E. A. Clarke, E. D. Nishri, and T. W. Anderson, "Childhood Leukemia in the Vicinity of Canadian Nuclear Facilities," Cancer Causes and Control, Vol. 4, No. 1, 1993, pp. 51-58. doi:10.1007/BF00051714

[29] Great Lakes Health Effects Program, "Atlas II, Cancer Incidence in the Great Lakes Region, Ontario: 19841988," Health Canada, Ottawa, Ontario, 1992. 
[30] Great Lakes Health Effects Program, "Atlas I, Birth Defects Atlas of Ontario: 1978-1988," Health Canada, Ottawa, Ontario, 1992

[31] Great Lakes Health Effect Program, "Port Hope Harbour Area of Concern: Health Data and Statistics for the Population of the Region (1986-1992), ATechnical Report for the RAP Community," 1998.

[32] Health Canada, "Cancer Incidence in Port Hope 19711996. Final Report. CNSC Report INFO-0716," Canadian Nuclear Safety Commission, Ottawa, Canada, 2000,

[33] Health Canada, "Cancer and General Mortality in Port Hope, 1956-1997. Final Report," CNSC Report INFO0734, Canadian Nuclear Safety Commission, Ottawa, Canada, 2002.

[34] Haliburton, Kawartha, Pine Ridge (HKPR) District Health Unit, "Cancer in the HKPR District Report," 2008. http://www.hkpr.on.ca/topics-master.asp?id=3418.

[35] Haliburton, Kawartha, Pine Ridge (HKPR) District Health Unit, "Rapid Risk Factor Surveillance System (RRFSS) Survey Results,” 2006. https://www.hkpr.on.ca/index.asp?id=3334.

[36] R. E. M. Lees, R. Steele and J. H. Roberts, 'Study of the Health Effects of Low-Level Exposure to Environmental Radiation Contamination in Port Hope, Ontario," RA569. 527,1984

[37] R. E. Lees, R. Steele and J. H. Roberts, "A case control study of lung cancer relative to domestic radon exposure," International Journal of Epidemiology, Vol. 16, No. 1, 1987, pp. 7-12. doi:10.1093/ije/16.1.7

[38] J. R. McLaughlin, W. D. King, T. W. Anderson, E. A. Clarke and P. J. Ashmore, "Paternal Radiation Exposure and Leukemia in Offspring: The Ontario Case-Control Study," British Medical Journal (BMJ), Vol. 307, No. 6901, 1993, pp. 959-966. doi:10.1136/bmj.307.6910.959

[39] C. Nair, J. D. Abbatt, G. R. Howe, H. B. Newcombe, and S. E. Frost, "Mortality Experience among Workers in the Uranium Industry," Occupational Radiation Safety in Mining, Toronto, Canadian Nuclear Association Proceedings of the International Conference, Vol. 1, 1984, pp. 354-364.

[40] R. S. D. Lane, S. E. Frost, G. R. Howe and L. B. Zablotska, "Mortality (1950-1999) and Cancer Incidence (19691999) in the Cohort of Eldorado Uranium Workers," Radiation Research, Vol. 174, No. 6A, 2010, pp. 773-785. doi:10.1667/RR2237.1

[41] Public Health Agency of Canada (PHAC), "Leading Causes of Death and in Canada," 2004. http://www.phac-aspc.gc.ca/publicat/lcd-pcd97/table1-en g.php

[42] United Nations, "Effects of Ionizing Radiation," Volume I. United Nations Scientific Committee on the Effects of Atomic Radiation, UNSCEAR 2006 Report to the General Assembly with Scientific Annexes A and B, United Nations, New York, 2008.

[43] Heart and Stroke Foundation, Ontario, "What is Heart
Disease?" 2008

http://www.heartandstroke.on.ca/site/c.pvI3IeNWJwE/b.4 007287/k.5D14/What is heart disease.htm

[44] International Commission on Radiological Protection (ICRP), "Recommendations of the International Commission on Radiological Protection ICRP Publication 103," Annals of the ICRP, Vol. 37, No. 2-4, 2007, pp. 137-246.

[45] Harvard School of Public Health, "Cancer Fact Sheet," October 2008

http://www.diseaseriskindex.harvard.edu/update/hccpquiz .pl?lang=english\& func $=$ home\&quiz $=$ lung.

[46] American Cancer Society, "Cancer Reference Information. Detailed Guide: Oral Cavity and Oropharyngeal Cancer," 2007.

http://www.cancer.org/docroot/CRI/content/CRI 244 2X _What_are the_risk_factors_for_oral_cavity_and_oropha ryngeal_cancer_60.asp?sitearea

[47] Institute of Medicine (IOM), "Committee on Gulf War and Health: Updated Literature Review of Depleted Uranium. Gulf War and Health: Updated Literature Review of Depleted Uranium," National Academy Press, Washington DC, 2008.

[48] The Royal Society, "The Health Hazards of Depleted Uranium Munitions, Part I," Royal Society, London, 2001

http://royalsociety.org/displaypagedoc.asp?id=11496.

[49] The Royal Society, "The Health Hazards of Depleted Uranium Munitions, Part II," Royal Society, London, 2002

http://royalsociety.org/displaypagedoc.asp?id=11498.

[50] J. D. Boice Jr., W. L. Bigbee, M. Mumma and W. J. Blot, "Cancer Incidence in Municipalities near Two Former Nuclear Materials Processing Facilities in Pennsylvania," Health Physics, Vol. 85, No. 6, 2003, pp.678-690. doi:10.1097/00004032-200312000-00013

[51] J. D. Jr. Boice, M. Mumma and W. J. Blot, "Cancer and Non-Cancer Mortality in Populations Living near Uranium and Vanadium Mining and Milling Operations in Montrose County, Colorado, 1950-2000," Radiation Research, Vol. 167, 2007, pp. 711-726. doi:10.1667/RR0839.1

[52] M. Tirmarche, H. Baysson and M. Telle-Lamberton, "Uranium Exposure and Cancer Risk: A Review of Epidemiological Studies," Revue d'épidemiologie et de santé publique, Vol. 52, No. 1, 2004, pp. 81-90.

[53] J. D. Boice Jr., M. Mumma, S. Schweitzer and W. J. Blot, "Cancer Mortality in a Texas County with Prior Uranium Mining and Milling Activities, 1950-2001," Journal of Radiological Protection, Vol. 23, 2003, pp. 247-262. doi:10.1088/0952-4746/23/3/302

[54] E. A. Dupree, J. P. Watkins, J. N. Ingle, P. W. Wallace, C. M. West and W. G. Tankersley, "Uranium Dust Exposure and Lung Cancer Risk in Four Uranium Processing Operations," Epidemiology, Vol. 6, No. 4, 1995, pp. 370-375. doi:10.1097/00001648-199507000-00007 
[55] J. D. Jr. Boice, R. W. Leggett, E. D. Ellis, et al., “A Comprehensive Dose Reconstruction Methodology for Former Rocketdyne/Atomic International Radiation Workers," Health Physics, Vol. 90, No. 5, 2006, pp. 409430. doi:10.1097/01.HP.0000183763.02247.7e

[56] J. D. Jr. Boice, S. S. Cohen, M. Mumma, B. Chadda and W. J. Blot, "A Cohort Study of Uranium Millers and Miners of Grants, New Mexico, 1979-2005," Journal of Radiological Protection, Vol. 28, No. 3, 2008, pp. 303325. doi:10.1088/0952-4746/28/3/002

[57] J. D. Jr. Boice, M. Mumma, S. Schweitzer and W. J. Blot., "Cancer Mortality in a Texas County with Prior Uranium Mining and Milling Activities, 1950-2001," Journal of Radiological Protection Vol. 23, 2003, pp. 247-262. doi:10.1088/0952-4746/23/3/302
[58] A. Auvinen, I. Makelainen, M. Hakama, et al., "Indoor Radon Exposure and Risk of Lung Cancer: A Nested Case Control Study in Finland," Journal of the National Cancer Institute, Vol. 88, No. 14, 1996, pp. 996-972. doi:10.1093/jnci/88.14.966

[59] A. Auvinen, P. Kurttio, J. Pekkanen, et al., "Uranium and Other Natural Radionuclides in Drinking Water and Risk of Leukemia: A Case-Cohort Study in Finland," Cancer Causes Control, Vol. 13, No.9, 2002, pp. 825-829. doi:10.1023/A:1020647704999

[60] P. Kurttio, A. Harmoinen, H. Saha, et al., "Kidney Toxicity of Ingested Uranium from Drinking Water," American Journal of Kidney Disease, Vol. 47, No. 6, 2006, pp. 972-982. doi:10.1053/j.ajkd.2006.03.002 